\title{
Distorsi Teologis terhadap Inkarnasi Kristus di dalam Teori Limitasi
}

\author{
The Theological Distortion of the Incarnation of Christ in \\ Limitation Theory
}

\section{E. Chrisna Wijaya}

Sekolah Tinggi Teologi Internasional Harvest Semarang

chrisnazhang@gmail.com

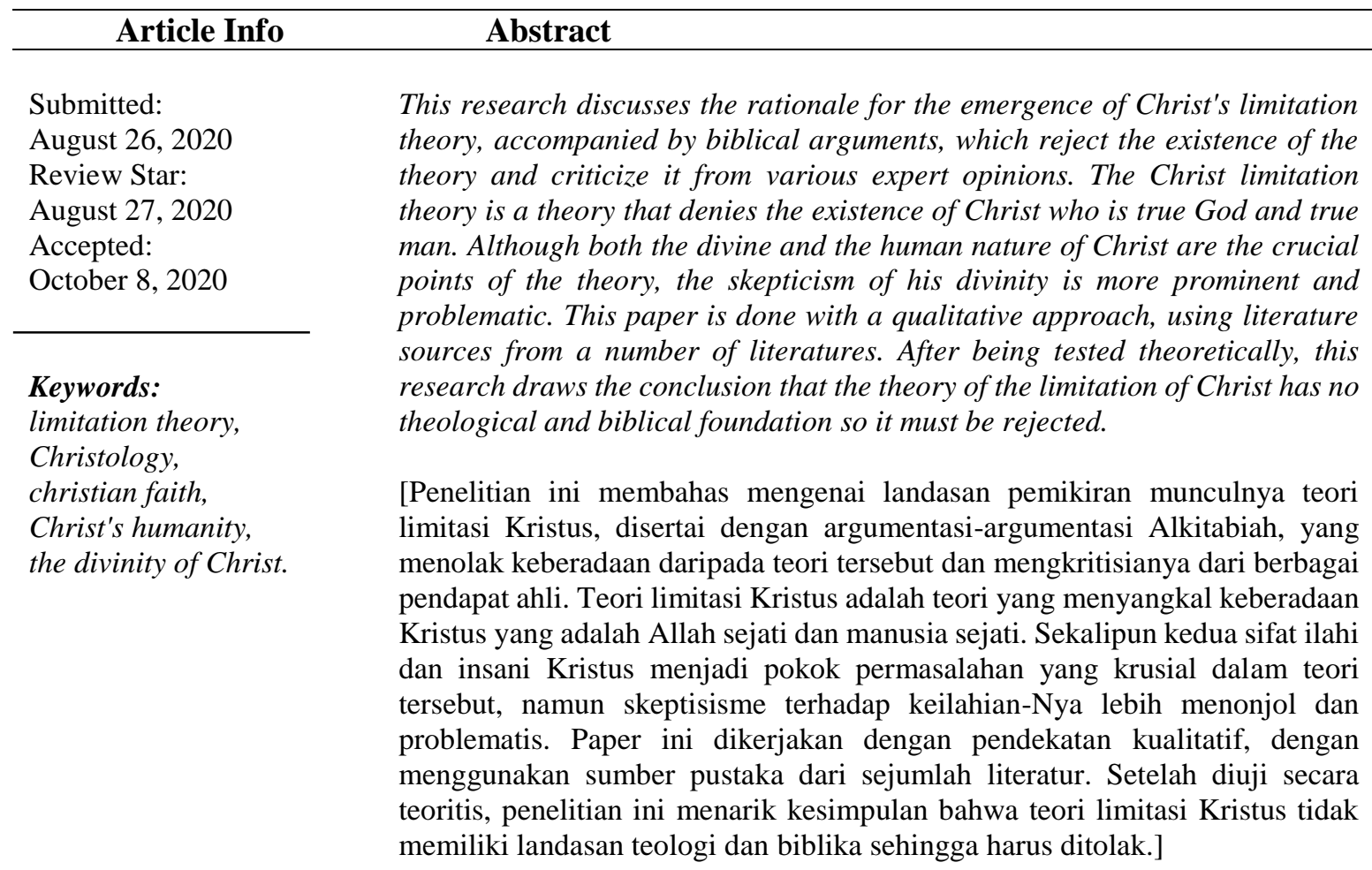




\section{PENDAHULUAN}

$\mathrm{D}$ i antara sekian banyak doktrin dalam jajaran Teologi Sistematika, doktrin tentang Kristus merupakan salah satu doktrin yang paling "empuk" dan paling sering melahirkan kontroversi yang tidak ada habis-habisnya mulai dari abad permulaan hingga masa kini, yang intinya adalah menyerang dan menjatuhkan paham ortodoks (kepercayaan mula-mula yang didasarkan pada kebenaran Alkitab), salah satunya adalah tentang Teori Limitasi Kristus. Terminologi tersebut dirumuskan oleh seorang apologis Kristen yang bernama Norman L Geisler. Menurut Geisler, terdapat dua pilar yang mendukung argumentasi dari teori keterbatasan yaitu kemanusiaan Kristus dan teori kenosis, ${ }^{1}$ yang telah dimunculkan dan dikembangkan oleh para bidat dari masa ke masa. Sifat ilahi dan sifat insani-Nya, yaitu keberadaan dua sifat dalam satu pribadi, sangat sulit dipahami dan diterima oleh golongan yang memegang paham limitasi tersebut. Di satu pihak ada yang tidak mempercayai keilahian Kristus, di pihak yang lain, ada yang skeptis dengan kemanusiaan-Nya. Kalaupun menerima kemanusiaanNya, keilahian-Nya ditolak dan begitu pula sebaliknya. Sekalipun kedua sifat ilahi dan insani Kristus menjadi pokok permasalahan yang krusial dalam teori tersebut, namun skeptisisme terhadap keilahian-Nya lebih menonjol dan problematis.

Inkarnasi Kristus merupakan "benih" masalah yang dijadikan sebagai penyebab yang melatarbelakangi munculnya teori limitasi Kristus. Pribadi kedua dari Allah Tritunggal yang berinkarnasi, menyebabkan dari masa ke masa hingga kini terus bermunculan perdebatan di sanasini, baik yang datang dari pihak yang merongrong doktrin Kristologi yang Alkitabiah, maupun yang berupaya untuk membelanya. Hal ini wajar, oleh karena inkarnasi Kristus merupakan inti dari Kekristenan, seperti yang diungkapkan oleh John F. Walvoord, demikian: "Inkarnasi Tuhan Yesus Kristus adalah bukti utama yang merupakan inti Kekristenan. Seluruh susunan teologia Kristen bergantung kepada inkarnasi Kristus ini. ... Karena barangkali, tidak ada bagian lain dari Kitab Suci yang diselidiki dengan lebih keras, dan menjadi sasaran lebih banyak perdebatan teologis dari pada keempat kitab Injil."

Ungkapan yang senada juga diberikan oleh R.C. Sproul, sebagai berikut: "Allah Anak mengambil natur manusia merupakan doktrin krusial dalam sejarah kekristenan. ..." ${ }^{3} \mathrm{C}$. Matthew Mcmahon, memberikan pandangannya tentang inkarnasi bahwa inkarnasi Anak Allah merupakan salah satu kebenaran yang paling diberkati dalam Alkitab. Hal tersebut merupakan doktrin yang penting dari iman Kristen. Tanpa itu, seseorang belum mempunyai iman Kristen. ${ }^{4}$

Terminologi Inkarnasi berasal dari kata Latin "incarnatio," yang berasal dari dua akar kata "in" yang memiliki arti, "masuk ke dalam" dan kata "carno/carnis," yaitu "daging." Secara harafiah, pengertian dari istilah inkarnasi adalah "masuknya Kristus ke dalam daging manusia." Tony Evans, secara sederhana memberikan pengertian tentang inkarnasi, yaitu“menjadi daging," yang berarti: Allah menjadi seorang manusia." Dengan demikian, Inkarnasi Kristus adalah

\footnotetext{
${ }^{1}$ Norman L. Geisler, "Baker Encyclopedia of Christian Apologetics" (Grand Rapids: Baker
} books, 2000), 425.

2 John F Walvoord, Yesus Kristus Tuhan Kita (Surabaya: Yakin, 1969), 86.

${ }^{3}$ RC Sproul, Kebenaran-Kebenaran Dasar Iman Kristen (Malang: SAAT, 1997), 111.

${ }^{4}$ C. Matthew Mcmahon, “A Meditation on the Doctrine of the Person of Christ," n.d., 16 Maret 2019, http://www.apuritansmind.com/ChristianWalk/McMahonMeditationIncarnation.htm.

${ }^{5}$ G.C. Van dan B.J. Boland Niftrik, Dogmatika Masa Kini (Jakarta: BPK Gunung Mulia, 1993), 226.

\footnotetext{
${ }^{6}$ Tony Evans, Teologi Allah (Malang: Gandum Mas, 1999), 334.
} 
Pribadi kedua Allah Tritunggal menjadi manusia di dunia. Dialah Yesus Kristus dalam keberadaannya yang adalah manusia itulah, menebus dosa umat manusia.

Berdasarkan hal tersebut, maka menarik untuk melakukan penelitian terhadap teori yang berupaya untuk memberikan pembatasan bahkan mencoba untuk menghilangkan sifat keilahian Kristus, karena keberadaan inkarnasi-Nya sebagai manusia sejati.

\section{METODE}

Penelitian terhadap subjek ini menggunakan metode riset kualitatif deskriptif tentang teologi sistematika, yaitu riset pada topik kristologi. Dalam melaksanakan penelitian ini, peneliti melakukan studi literatur terhadap salah satu isu Kristologi, yaitu tentang limitasi Kristus, guna memperoleh pemahaman serta keyakinan para pakar yang pro dan kontra terhadap isu tersebut. Hal yang demikian dijelaskan oleh Otieli Harefa yang mengutip penjelasan dari Lexi J. Moleong, bahwa metode penelitian kualitatif adalah sebuah penelitian yang secara holistik dan deskriptif untuk memahami dan mendalami konsep, perilaku, persepsi, motivasi dan tindakan serta hal-hal lainnya dengan memanfaatkan data-data yang ada. ${ }^{7}$ Sumber literatur yang digunakan dalam penelitian ini adalah Alkitab dan artikel-artikel yang berhubungan erat dengan keilahian Kristus, serta buku-buku mengenai Kristologi. Di samping itu juga beberapa buku dan informasi pendukung yang berhubungan erat dengan subjek penelitian ini yang dapat digunakan sebagai sumber penelitian, yang peneliti uraikan secara deskriptif. Selanjutnya peneliti membuat kesimpulan mengenai subjek penelitian tersebut. Dalam pelaksanaan penelitian, penulis melakukan penyesuaian dengan penelitian yang dilaksanakan. Pelaksanaa prosedur penelitian ini melalui 9 tahapan, yang dimulai dari tahap rancangan penelitian, pengumpulan referensi sumber penelitian, pembuatan judul deskripsi, penyusunan kerangka, review pakar, tesis-antitesis-sintesis, revisi laporan hingga tahap akhir yaitu penulisan laporan.

\section{PEMBAHASAN}

Sekalipun pelecehan atau penyimpangan yang ditujukan kepada Kristologi semata-mata merupakan masalah yang bersifat Kristiani, seperti yang dinyatakan Bernhard Lohse, bahwa Kristologi merupakan pengajaran yang mengkaji secara mendalam tentang hubungan antara sifat ilahi dan sifat insani yang terdapat dalam pribadi Yesus Kristus. ${ }^{8}$ Namun demikian, tidak dapat dipungkiri bahwa baik tokoh-tokoh apologetik Kristen maupun tokoh-tokoh bidat dalam upaya memahami Kristologi, memakai pemikiran-pemikiran yang berasal dari filsafat. Dalam penjelasannya Lohse menambahkan juga bahwa para apologet memiliki pemahamban bahwa konsep logos tidak kalah penting dengan pemahaman mengenai Yesus Kristus sendiri. Konsep logos tidak lagi dipahami sebagaimana yang terdapat dalam pemahaman Injil Yohanes, yang adalah Firman Allah yang tampil dalam sejarah, namun dipahami sebagai akal universal dan prinsip kosmis. Dengan demikian para apologet menyamakan pra-eksistensi Kristus dengan konsep logos dari filsafat Yunani. Hal tersebut membuat pembelajar pada masa itu mengalami kemudahan dalam memahami pemikiran Kekristenan pada masa tersebut. Pemahaman yang dibangun dengan cara tersebut, membuat kaum apologet dapat berkata bahwa seluruh kebenaran yang dimiliki oleh para filsuf Yunani pada akhirnya berasal dari Logos, yaitu Yesus Kristus.

${ }^{7}$ Otieli Harefa, "Implikasi Teologis Baptisan Air Pada Keselamatan," PASCA: Jurnal Teologi Dan Pendidikan Agama Kristen 16, no. 1 (2020): 1-14, https://doi.org/10.46494/psc.v16i1.78.

${ }^{8}$ Bernhard Lohse, Pengantar Sejarah Dogma Kristen (Jakarta: BPK Gunung Mulia, 1999), 90. 
Konsep logos dalam filsafat kuno muncul muncul secara fragmentaris dan tidak sempurna, yang selanjutnya menyatakan dirinya secara sempurna dalam pribadi Yesus Kristus. Selanjutnya melalui pengaruh Origenes, kristologi logos menjadi semakin solid pada abad ke-3, yang awalnya dihanya dianggap sebagai praduga, kemudia diakui secara universal dalam pemikiran Kristologi selanjutnya. Arius sendiri menerima konsep logos tersebut, meskipun interpretasi mengenai hal itu itu berbeda dengan interpretasi kaum apologet dan Origenes. ${ }^{9}$

Petrus Maryono memberikan juga pandangannya yang tidak berbeda dengan pernyataan di atas, bahwa hal tersebut juga terjadi pada ajaran Tritunggal, ajaran tentang pribadi Kristus pada dasarnya telah terbentuk pada zaman gereja lama/kuno. Masa reformasi maupun masa abad pertengahan sama sekali tidak menghasilkan sesuatu yang baru terhadap doktrin ini. Penyimpangan terhadap doktrin tentang pribadi Kristus muncul karena adanya ajaran Servetus, yang dari ajaran tersebut lahirlah gerakan Socianianisme dan akhirnya berkembang menjadi gerakan Unitarianisme baik di UK maupun di USA. Gereja pada masa modern ditandai dengan penafsiran kembali terhadap nilai-nilai lama. Dan ini menyebabkan terjadinya pengangkatan ulang berbagai azas dasar Kekristenan. Ingatlah kembali pengaruh tokoh-tokoh, seperti: Descartes, Hobber, Locke, Kant serta pengaruh para filsuf tersebut terhadap kehidupan teologia akal dan subyektivitas telah dianggap menjadi otoritas akhir dalam pemikiran teologia. ${ }^{10}$

Filsafat diklaim oleh cukup banyak orang sebagai induk yang melahirkan segala ilmu pengetahuan yang ada di muka bumi ini, seperti yang diungkapkan oleh Jan Hendrik Rapar, sebagai berikut: Filsafat adalah mater scientiarum atau induk ilmu pengetahuan. Filsafat disebut sebagai induk ilmu pengetahuan karena memang filsafatlah yang telah melahirkan segala ilmu pengetahuan yang ada. Jauh dari keinginan untuk mendewakan dan memuliakan filsafat, kehadirannya yang terus-menerus di sepanjang sejarah peradaban manusia sejak kelahirannya sekitar dua puluh lima abad yang lalu telah memberi kesaksian yang meyakinkan tentang betapa pentingnya filsafat bagi manusia. ${ }^{11}$

Secara etimologi, kata filsafat yang dalam bahasa Inggris, dipakai istilah philosophy berasal dari bahasa Yunani $\phi \iota \lambda о \sigma o \phi \iota \alpha$ (philosophia), yang terdiri dari dua akar kata, yaitu: $\phi \iota \lambda \circ \varsigma$ (philos), yang berarti "kasih, cinta," dan kata: бофı $\alpha$ (sophia), yang artinya: "kebijaksanaan, pengetahuan." Dengan demikian, istilah philosophia atau filsafat berarti: "mencintai pengetahuan." Rapar mengungkapkan pendapatnya tentang pandangan para filsuf terhadap filsafat, dengan penjelasan bahwa beberapa filsuf, di antaranya seperti Plato pernah menjelaskan bahwa filsafat adalah ilmu pengetahuan yang berusaha meraih kebenaran yang asli dan murni, di samping itu, filsafat juga memberikan penyelidikan tentang sebab-sebab dan asas-asas yang paling akhir dari segala sesuatu yang ada. Sementara Aristoteles, yang adalah murid Plato, mengajarkan bahwa filsafat adalah ilmu pengetahuan yang senantiasa berupaya mencari prinsipprinsip dan penyebab-penyebab dari realitas ada. filsafat adalah ilmu pengetahuan yang berupaya mempelajari "peri ada selaku peri ada" (being as being) atau "peri ada sebagaimana adanya" (being as such). Rene Descartes, seorang filsuf Perancis yang termasyhur dengan argument je pense, donc je suis, atau dalam bahasa Latin cogito ergo sum ("aku berpikir maka aku ada"), menjelaskan teorinya tentang filsafat yang adalah himpunan dari segala pengetahuan yang

\footnotetext{
${ }^{9}$ Lohse, 97.

${ }^{10}$ Petrus Maryono, Diktat Kuliah: Sejarah Doktrin (Yogyakarta, 2007), 9.

${ }^{11}$ Jan Hendrik Rapar, Pengantar Filsafat (Yogyakarta: Kanisius, 2005), 5.
} 
pangkal penyelidikannya adalah mengenai Tuhan, alam, dan manusia. ${ }^{12}$ Kecintaan para filsuf terhadap pengetahuan dan hasil pemikiran pengetahuan mereka menempatkan akal manusia di atas segalanya. Terry Hebert dalam perkuliahannya Metode Pendidikan Kristen, mengatakan: zaman pencerahan, modern dan posmodernisme merupakan tiga hal yang menyebabkan turunnya sejarah dan filsafat narasi dalam metode pendidikan Kristen. Salah satu fokus dari pada pandangan-pandangan tersebut sangat mengutamakan akal. ${ }^{13}$ Entah bidat-bidat Kristen mengakui atau tidak, tetapi dengan menjunjung tinggi akal manusia dan tidak jarang mengesampingkan iman, para bidat mendasari pemikirannya terhadap doktrin Kristiani mereka, seperti yang diutarakan oleh Marantika: Pada zaman ini metode induktif dan metode empiris mendapat tekanan yang kuat. Sains berkembang. Ilmu-ilmu baru bermunculan. Pengetahuan akal (keyakinan terhadap kemampuan akal) ditinggikan bersama sikap toleransi terhadap berbagai pandangan yang berbeda-beda. ${ }^{14}$

Berdasarkan pemikiran tersebut, hal-hal yang di luar akal manusia dianggap tidak relevan dan bukanlah sebuah kebenaran yang perlu diterima. Bagi para bidat, kebenaran adalah sesuatu yang bisa dipahami dan diterima oleh akal manusia, sehingga tidak dapat dipungkiri bahwa salah satu paham teologi modern yang ajarannya sangat kuat menancapkan bisanya di sendi-sendi Kekristenan yaitu Liberalisme juga melandasi pemikiran dengan akal, sebagaimana yang dipaparkan oleh Daun, bahwa pada umumnya pengajaran Liberalisme/Modernisme berawal pada rasio manusia sebagai landasan dan otoritas tertinggi dari iman. Semua hal atau pengajaran yang terdapat di dalam Alkitab boleh diterima, asal tahan terhadap ujian rasio manusia. Hal-hal yang tidak masuk akal, ditolak mentah-mentah! ${ }^{15}$

\section{Eksistensi Inkarnasi}

Eksistensi Kristus yang berinkarnasi, Allah yang mengambil rupa manusia, memang tidak mudah dipahami dengan rasio. Herman Bavinck dalam pernyataannya mengakui bahwa pengakuan dan pemikirian mengenai eksistensi dari konsep mengenai satu pribadi yang memiliki dua sifat, yaitu ilahi dan insani, merupakan hal yang tidak mudah bahkan sulit untuk dipahami. Dua isu atau problem yang nyata muncul, yang menjadi topik perdebatan hinggal sekarang ini adalah, "Jika Yesus tidak berdosa, bisakah ia benar-benar menjadi manusia yang seutuhnya?" Sementara itu isu yang lain adalah, "Jika ia telah berada dalam pembatasan, bagaimana ia bisa sungguh-sungguh Tuhan?"16 Dalam konteks pembahasan tentang pribadi Kristus yang berinkarnasi dengan memakai kaca mata filsafat, keilahian dan kemanusiaan Kristus sebagai kesatuan yang tak terpisahkan dan tak bercampur sangat sulit untuk diterima oleh akal manusia. Lohse memberikan pendapatnya bahwa: tidak dapat dihindari bahwa perkembangan yang dimulai dari ide-ide kristologi yang berasal dari Kekristenan purba dan yang membawa sampai pada ajaran tentang dua sifat, kemudian bukannya tidak bersifat linier. Dalam sejarah kristologi, sebagaimana halnya dalam sejarah ajaran tentang Allah, telah banyak upaya yang bersifat mencari-cari namun tidak pernah diterima secara umum. Pada mulanya terdapat sejumlah besar variasi dari konsepsi-

\footnotetext{
12 Rapar, 15.

13 Terry Hebert, Catatan Kuliah: Metode Pendidikan Kristen (Yogyakarta, 2006).

${ }^{14}$ Chris Marantika, Diktat Kuliah: Filsafat Dan Apologetika (Yogyakarta, 2006), 23.

${ }^{15}$ Paulus Daun, Bidat Kristen Dari Masa Ke Masa (Manado: Yayasan Daun Family, n.d.), 79.

${ }^{16}$ Herman Bavinck, "The Divine and Human Nature of Christ," n.d., 15 Desember 2019, www.graceonlinelibrary.org.
} 
konsepsi kristologi. Berangsur-angsur konsepsi yang banyak ini dibakukan dalam beberapa pola yang secara tajam dibedakan satu terhadap yang lain. Sejak itu kita hanya dapat mengikuti garis perkembangan yang mengarah pada ajaran mengenai dua sifat, ${ }^{17}$ Sehingga pada awal abad permulaan bermunculan pandangan-pandangan yang berupaya untuk memberikan penjelasan tentang keberadaan Kristus dengan kedua sifat-Nya, dengan pandangan-pandangan yang dapat diterima oleh akal manusia. Di antaranya, seperti: Ebionisme, Doketisme, Gnostisisme dan pandangan-pandangan sumbang lainnya.

Intinya, dengan landasan pemikiran dan landasan penelitian yang mengutamakan rasio, memberikan pandangan-pandangan yang ekstrem terhadap Kristus. Ekstrem pertama, Kristus adalah manusia sejati, dan bukan Allah sejati, yang berarti di sini ada pembatasan terhadap keilahian Kristus. Sedangkan ekstrem kedua, Kristus benar-benar Allah sejati, sedangkan kemanusiaannya tidak sejati.. Masih banyak ajaran-ajaran ekstrem lainnya tentang Kristus dari pada bidat yang mendasari pemikiran Kristologinya dengan filsafat, sehingga menghasilkan pemahaman atau keyakinan bahwa Kristus adalah pribadi yang memiliki batasan-batasan dari sisi ilahi-Nya dan ketidaksejatian kemanusiaan-Nya.

\section{Teori Limitasi Kristus}

Berdasarkan arti kata yang diperoleh dari kamus, teori limitasi Kristus secara mudah dapat dipahami sebagai teori yang membahas tentang keterbatasan atau pembatasan Kristus. Namun demikian, arti tersebut belum secara gamblang atau tidak cukup memberikan pemahaman arti yang sebenarnya, terutama bagi orang-orang yang mendengar atau membaca istilah tersebut.

Sepakat dengan pemahaman yang dijelaskan oleh Lohse, bahwa masalah Kristologi adalah bersifat Kristen, Sangat jelas bahwa yang terjadi di sini adalah suatu persoalan yang secara khusus bersifat Kristen. Sementara memang benar bahwa ajaran tentang Trinitas tidak berasal dari sumber-sumber bukan Kristen, tidak dapat dikatakan bahwa masalah keesaan Allah sungguhsungguh hanya bersifat Kristen saja; masalah Allah juga bersifat filosofis. Pada pihak lain, dalam Kristologi kita berhadapan dengan masalah yang sungguh-sungguh murni Kristen, ${ }^{18}$ maka peneliti berusaha mengangkat pengertian dari sudut pandang teologis Kristiani. Dengan memberikan pengertian teologis, berarti memberikan pengertian terhadap limitasi Kristus dengan menggunakan pemikiran-pemikiran teologi.

Menurut pemahaman Paul Enns, secara umum teologi merupakan sebuah istilah yang memiliki arti yang luas yaitu meliputi keseluruhan aspek kepercayaan iman Kristen. ${ }^{19}$ Kristologi adalah doktrin yang mendominasi Alkitab dan bukan hanya itu saja, tema dari Kitab Kejadian sampai Kitab Wahyu adalah tentang Yesus Kristus. Hal yang demikian diungkapkan oleh John F. Walvoord: "Dari kitab Kejadian sampai dengan kitab Wahyu, Yesus Kristus merupakan tema paling penting dari Alkitab. Hampir setiap lembar Alkitab mempunyai hubungan tertentu dengan pribadi Yesus atau pekerjaan-Nya." 20 Dalam sebagian pernyataan doktrinalnya, Seminari Theologia Dallas, berkata bahwa: "Kami percaya bahwa keseluruhan Alkitab berpusat tentang Tuhan Yesus Kristus dalam pribadi-Nya dan karya-Nya pada kedatangan pertama dan kedua-

\footnotetext{
${ }^{17}$ Lohse, Pengantar Sejarah Dogma Kristen, 93.

${ }^{18}$ Lohse, 90-91.

${ }^{19}$ Paul Enns, The Moody Handbook of Theology (Malang: Literatur SAAT, 2004), 223.

${ }^{20}$ Walvoord, Yesus Kristus Tuhan Kita, 6.
} 
Nya, ..."21 Sekalipun Kristologi memiliki aspek yang begitu luas, namun dalam penelitian ini, penulis hanya menjelaskan pengertian yang berkaitan dengan teori limitasi Kristus sebagai bentuk penyimpangan teologis terhadap inkarnasi Kristus yang menjadi topik dalam penelitian ini.

Secara teologis, peneliti beranggapan bahwa teori limitasi Kristus merupakan bentuk penyimpangan teologis terutama terhadap Kristus yang berinkarnasi. Hal tersebut disebabkan karena teori ini berisi pandangan atau keyakinan yang memberikan pembatasan terhadap keilahian Kristus oleh karena keberadaan-Nya yang mengambil rupa manusia di dunia, seperti yang diungkapkan oleh A.E. Knoch bahwa: Seandainya orang percaya menganggap bahwa istilah teologi bukan alkitabiah, maka orang percaya akan terjerumus dalam lumpur berkabut yang membuat teologi menjadi terperosok. Sebagai contoh seorang penulis baru berkata, "Walaupun Tuhan secara mutlaknya ialah Roh dan tidak kelihatan, dan seorangpun tidak pernah dan tidak dapat melihatNya, namun untuk tujuan penciptaan Dia mengenakan pada diriNya batasanbatasan yang dinyatakan melalui gelar-gelar, seperti 'Gambaran Tuhan yang Tidak Kelihatan,' 'Rupa Tuhan,' dan 'Firman,' dan untuk tujuan penebusan Dia membatasi lagi diriNya dengan menjadi manusia dan berdiam di tengah-tengah manusia sebagai Anak Tunggal Bapa. Meskipun adanya semua batasan itu. . . Penulisan ini perlu dilakukan, karena ingin menarik perhatian kepada istilah bukan alkitabiah sebagai batasan (limitasi), yang merupakan kunci kepada teori yang diajukan. Jika ini betul maka salah satu doktrin terbesar dalam Kitab Suci pastinya ialah Batasan-batasan Ketuhanan. ${ }^{22}$ Sebagaimana pernyataan yang dituliskan oleh Norman L. Geisler, sebagai berikut: "Teori pembatasan jadi lebih masuk akal dan berpotensi merusakkan teori akomodasi. Tetapi kedua argumentasi yang mengarah ke pembatasan dari Kristus sepakat mengabaikan poin-poin penting tentang siapakah Yesus." ${ }^{23}$

Dari pemikiran-pemikiran di atas, peneliti mengambil kesimpulan bahwa yang dimaksudkan dengan teori limitasi Kristus adalah teori yang berusaha merontokkan iman Kristiani dengan pandangan dan keyakinan bahwa ada batasan-batasan ke-Allah-an Kristus, oleh karena keberadaan-Nya yang mengambil rupa manusia (inkarnasi).

\section{Isu-isu yang Berkembang}

Pemikiran yang didasarkan pada inkarnasi Kristus, pribadi kedua Allah yang menjadi manusia dan teori kenosis, yang melatarbelakangi munculnya teori limitasi Kristus, berkembang menjadi beberapa isu-isu yang sumbang mengenai Kristus. Di antaranya seperti yang disampaikan oleh beberapa teolog injili. Geisler, memberikan beberapa isu yang dimunculkan oleh teori tersebut, yang antara lain: "Pengetahuan kemanusiaan yang terbatas, ... Pengosongan pada inkarnasi, ... Dapatkah Kristus berbuat salah atau berdosa? . . ${ }^{24}$ Sebenarnya yang menjadi isu utama dari teori pembatasan Kristus, adalah "pembatasan keilahian Kristus." Namun seiring dengan kasus-kasus yang diangkat ke permukaan oleh teori tersebut, akhirnya juga menyinggung kemanusiaan Kristus yang sejati. Seperti anggapan mereka yang menyatakan bahwa pengetahuan Yesus terbatas adanya dan Yesus dapat berdosa atau tidak. Apabila jawaban yang diberikan

21 "Syrac Christianity," n.d., 15 Desember 2019, http://syracchristianity.com/sac/Chapter II.htm.

${ }^{22}$ A.E. Knoch, "Kristus Dan Ketuhanan," n.d., 23 Mei 2019,

http://www.logon.org/indonesian/s/p237.html, A.E. Knoch, Kristus dan Ketuhanan.

${ }^{23}$ Geisler, "Baker Encyclopedia of Christian Apologetics," 425.

${ }^{24}$ Geisler, "Baker Encyclopedia of Christian Apologetics." 
adalah Yesus mahatahu dan Ia tidak dapat berbuat dosa, maka Ia sempurna keilahian-Nya, justru kesempurnaan kemanusiaan-Nya dipertanyakan atau diragukan.

Mengenai anggapan-anggapan tersebut, Pannenberg and the Chalcedonian mengutarakan tentang sulitnya memahami konsep satu pribadi dengan dua sifat tesebut. ${ }^{25}$ Sedangkan Michael Bremmer dalam tulisannya memberikan penjelasan bahwa, Alkitab tidak menjelaskan dampak apa pun yang diakibatkan dari adanya kedua sifat terhadap satu sama lain, atau bagaimana keduaduanya akan bekerja bersama-sama, atau dengan bebas; atau bagaimana sifat kedua-duanya mendasari seseorang; atau bagaimana mungkin Pribadi Yesus Kristus menjadi secara manusia sejati namun juga menjadi Tuhan sejati serta kemungkinan terjadinya kepalsuan yang menegangkan, dan dapat menjadi pintu masuk ke bidat. ${ }^{26}$

Berdasarkan pernyataan-pernyataan dari para teolog di atas dan sebagaimana yang dari awal telah dibahas dan dijelaskan bahwa keberadaan teori limitasi Kristus, sebagai akibat dari kemanusiaan-Nya dan pengosongan diri-Nya (kenosis), yang mempermasalahkan keberadaan Kristus yang memiliki dua sifat, yaitu ilahi dan manusiawi. Yang mana permasalahan tersebut memunculkan dua isu yang mendominasi teori ini. Isu yang pertama adalah: Kristus bukan Tuhan sejati. Sedangkan isu kedua berisi, bahwa Kristus bukan manusia sejati. Teori tersebut mengembangkan argumentasi-argumentasi yang dipakai untuk menguatkan ajaran dan para pengikutnya.

\section{Kristus Bukan Allah Sejati}

Konsekuensi yang diterima oleh Kristus sebagai dampak dari inkarnasi dan pengosongan diriNya memunculkan anggapan-anggapan bahwa dalam keberadaan-Nya sebagai manusia biasa, Kristus memiliki batasan-batasan bagi keallahan-Nya, sehingga dalam kehidupan-Nya sebagai manusia, Ia bukanlah Allah secara penuh atau Allah sejati. Mengenai pemahaman yang demikian, Marantika mengangkat salah satu pandangan yang keliru tersebut, dengan penjelasan bahwa "The absolute dualistic type," memberikan perbedaan yang jelas antara immanent attributes (sifat-sifat immanent) dan Transendent attributes (sifat-sifat absolute). Menurut penganutnya sifat-sifat absolute seperti kemahahadiran, kemahatahuan, dan kemahakuasaan Kristus dilepaskan atau dihilangkan waktu menjadi manusia. Salah satu tokohnya adalah Athanasius. ${ }^{27}$ Komentarkomentar diberikan oleh beberapa tokoh, seperti: Bremmer, mengungkapkan pendapatnya bahwa: Teologi Kenosis merupakan ajaran yang paling sering menyatakan bahwa Kristus menyerahkan atribut-atribut ketuhanan yang relatif. Artinya di dalam penjelmaan, Kristus menyerahkan kemahatahuan-Nya, kemahakuasaan-Nya dan kemahahadiran-Nya. Sementara yang masih dipertahankan adalah kekudusan, kasih, kemurahan hati dan kebenaran. ${ }^{28}$ Ketaatan mutlak dari Kristus yang dengannya orang banyak beroleh kemuliaan anugerah karena diperhitungkan sebagai orang benar, yang didemonstrasikan dengan satu-satunya cara yaitu penderitaan dan

\footnotetext{
25 "Pannenberg and the Chalcedonian Creed.," n.d., 5 Maret 2019, http://freespace.virgin.net/linz.cullen/pannenberg.html.

${ }^{26}$ Michael Bremmer, "Kenotic Theology," n.d., 2 Januari 2015, http://www.mbrem.com/Jesus_Christ/keno.htm, Michael Bremmer, Kenotic Theology.

${ }^{27}$ Chris Marantika, Diktat Kuliah: Filsafat Dan Apologetika, 40.

${ }^{28}$ Michael Bremmer, "Kenotic Theology."
} 
kematian di atas kayu salib, ${ }^{29}$ justru dianggap oleh penganut limitasi Kristus, sebagai bukti bahwa Kristus Yesus bukanlah Allah sejati. Keyakinan bahwa Kristus melepaskan atribut keallahanNya, jelas hendak memunculkan pemahaman bahwa Ia bukan Allah. Thiessen sendiri secara tegas mengomentari pemikiran yang sumbang tersebut, dengan menyayangkan mengenai banyaknya para teologi yang melakukan kekeliruan atau kesalahan dalam menafsirkan tindakan mengosongkan diri itu. Pandangan yang keliru tersebut menjelaskan bahwa Kristus mengosongkan diri-Nya dari sifat-sifat yang relatif -- kemahatahuan-Nya, kemahakuasaan-Nya, dan kemahahadiran-Nya - sekalipun tetap mempertahankan sifat-sifat yang imanen - kekudusanNya, kasih-Nya, dan kebenaran-Nya. Bahkan secara keliru pula mengajarkan bahwa Kristus memiliki pengetahuan yang dalam, tetapi bukan pengetahuan yang sempurna; bahwa Ia berkuasa namun tidak mahakuasa. ${ }^{30}$

Mengenai pemikiran-pemikiran yang sumbang terhadap keallahan Kristus, dengan ungkapan yang sama dengan pendapat di atas, Ryrie memberikan tanggapannya, bahwa: Pengertian yang keliru ini Memberikan penjelasan bahwa kenosis artinya bahwa Tuhan sebenarnya menyerahkan gelar-gelar keallahan-Nya, atau paling tidak, gelar-gelar yang berkenaan dengan kemahahadiran-Nya, kemahakuasaan-Nya, dan kemahatahuan-Nya. ${ }^{31}$ Pro dan kontra mengenai ketuhanan Kristus terus-menerus diperdebatkan oleh kedua belah pihak. Mengenai hal tersebut, Peter Kreeft dan Ronald K. Tacelli, menyatakan mengenai perbedaan yang paling mendasar yang terdapat di antara kaum ortodoks, tradisional, alkitabiah, kerasulan, sejarah, pengakuan Kekristenan dan revisionis, dalam memahami eksistensi Kristus. Pemahaman kaum modern, Kekristenan yang liberal memandang secara sederhana sebagai manusia yang ideal, atau "manusia untuk yang lain"; sebagai nabi, rabbi, ahli filsafat, guru, pekerja sosial, psikolog, dokter jiwa, pembaharu, orang bijaksana atau tukang sihir- tetapi bukan Tuhan di dalam daging. ${ }^{32}$

\section{Kristus Bukan Manusia Sejati}

Sebenarnya dari kedua isu yang berkembang dalam teori ini, isu yang menyatakan bahwa: Kristus bukan Tuhan sejati, lebih ditonjolkan dan sangat mendominasi keberadaan teori ini. Namun bukan berarti keberadaan Kristus sebagai manusia yang sejati, tidak dipermasalahkan. Dalam bagian ini, Thiessen juga memberikan penjelasan bahwa kemanusiaan Kristus merupakan doktrin yang jarang diperdebatkan. Meskipun berkembang ajaran-ajaran sesat, seperti, Gnostisisme yang menyangkal realitas tubuh Kristus, dan ajaran Eutikhes yang menjadikan tubuh Kristus itu tubuh yang ilahi, namun penyimpangan dari doktrin Alkitab lebih banyak terjadi karena menolak sifat ilahi Kristus dan bukan menolak sifat insani-Nya. ${ }^{33}$

Berkaitan dengan persoalan kemanusiaan Kristus yang tidak mendapat serangan seheboh keilahian Kristus dari para bidat, Ryrie juga memberikan pernyataan yang tidak jauh berbeda, bahwa: Penolakan atau penyangkalan terhadap kemanusiaan Kristus lebih biasa dibandingkan dengan penolakan atau penyangkalan terhadap Keallahan-Nya. Selama seseorang atau orang-

\footnotetext{
${ }^{29}$ Sonny Zaluchu, "Penderitaan Kristus Sebagai Wujud Solidaritas Allah Kepada Manusia," DUNAMIS: Jurnal Penelitian Teologi Dan Pendidikan Kristiani, 2017, https://doi.org/10.30648/dun.v2i1.129.

${ }^{30}$ C. Henry Thiessen, Teologi Sistematika (Malang: Gandum Mas, 1997), 328.

${ }^{31}$ Charles C. Ryrie, Teologi Dasar (Yogyakarta: Andi offset, 2000), 335.

${ }^{32}$ Peter dan Ronald K. Tacelli Peter Kreeft, Handbook of Christian Apologetics. (Downer's Grove: InterVarsity Press, 1994), 151-52.

33 Thiessen, Teologi Sistematika, 333.
} 
orang tidak memasukkan faktor Keallahan ke dalam pribadi Kristus, maka Yesus hanyalah seorang manusia, betapapun baiknya atau ditinggikan. Dan sebagai manusia biasa, Yesus tidak dapat mengusik orang-orang dengan pengakuan-pengakuan-Nya, seperti ungkapan bahwa Yesus adalah Manusia-Allah. Walaupun demikian, mereka yang mungkin mudah mengiyakan kemanusiaan-Nya belum tentu mudah menerima kemanusiaan-Nya yang sempurna. ${ }^{34}$

Jadi, meskipun jarang dan tidak mendominasi, penyangkalan terhadap kemanusiaan Kristus yang sejati dari awal juga sudah merasuki sendi kekristenan, seperti yang diungkapkan Dister: "Topik yang paling ramai dibicarakan pada abad IV dalam rangka Kristologi ialah ada tidaknya jiwa manusiawi pada Yesus Kristus. Khususnya pemikiran Apollinaris dari Laodikia yang ikut mempengaruhi perkembangan abad berikutnya." 35 Yang hingga kini juga bergema dalam teori limitasi Kristus.

Argumentasi yang dikembangkan untuk mendukung pandangannya adalah mengenai sebuah pertanyaan: Dapatkah Kristus berbuat dosa? Bagi para apologis Kristen, jawaban terhadap pertanyaan ini ibarat makan buah simalakama, "makan, bapak mati, tidak makan, ibu yang mati." Maksudnya di sini, jika para teolog Kristen menjawab bahwa Kristus tidak dapat berbuat dosa, maka Kristus bukan manusia. Sedangkan jika mereka menjawab bahwa Kristus dapat berbuat dosa, maka Kristus bukanlah Tuhan.

Berdasarkan penjelasan-penjelasan yang dibeberkan Alkitab mengenai ketakberdosaan Kristus, seperti yang disaksikan dalam Ibrani 4:15: "Sebab Imam Besar yang kita punya, bukanlah imam besar yang tidak dapat turut merasakan kelemahan-kelemahan kita, sebaliknya sama dengan kita, Ia telah dicobai, hanya tidak berbuat dosa." "Dia yang tidak mengenal dosa telah dibuat-Nya menjadi dosa karena kita, supaya dalam Dia kita dibenarkan oleh Allah" (2Kor. 5:21).

Dari pernyataan-pernyataan yang menjelaskan bahwa Kristus adalah Pribadi yang tidak mengenal dosa, para bidat tahu dan mengakui bahwa selama hidup-Nya di dunia, Kristus tidak mengenal dosa dan tidak berbuat dosa. Oleh karena itu, pertanyaan tersebut dipertajam menjadi: Apakah Kristus memiliki potensi untuk berbuat dosa? Dalam hal ini, para bidat memiliki dugaan bahwa orang-orang Kristen ortodoks akan memberikan jawaban bahwa Kristus tidak dapat berbuat dosa, sehingga dengan jawaban tersebut, para bidat dapat membuktikan bahwa Kristus bukanlah manusia sejati.

\section{KESIMPULAN}

Teori limitasi Kristus memberikan beberapa keyakinan atau pemahaman baru bahwa: Pertama, Yesus Kristus bukanlah Tuhan sejati! Pemahaman yang dimunculkan oleh teori tersebut, jelas mendatangkan dampak teologis yang semakin parah dan berbahaya bagi iman Kristiani. Karena dengan membatasi keilahian Kristus, berarti juga membatasi karya penebusan dan penyelamatan-Nya atas dunia ini. Kedua, Penyangkalan atau pembatasan terhadap Kristus sebagai Tuhan sejati, juga memunculkan penyangkalan terhadap kekekalan Kristus. Ketiga, Penyangkalan-penyangkalan yang ditudingkan terhadap keilahian dan kemanusiaan Kristus dari pihak-pihak pendukung limitasi Kristus yang skeptis terhadap pribadi Kristus yang adalah Allah dan manusia sejati, ternyata memberikan efek yang dapat menghancurkan iman kekristenan yang

\footnotetext{
${ }^{34}$ Charles C. Ryrie, Teologi Dasar, 337.

${ }^{35}$ Nico Syukur Dister, Teologi Sistematika (Yogyakarta: Kanisius, 2004), 186-87.
} 
ortodoks, sehingga umat Kristiani tidak lagi menganggap dan mempercayai bahwa Yesus Kristus adalah Juruselamat manusia.

Oleh karena itu diperlukan bukan hanya pemahaman yang benar tentang Kristologi yang Alkitabiah, tetapi juga dibutuhkan pembelaan-pembelaan iman yang Kristologis pula dari para apologis Kristen. Dengan demikian, masih banyak peluang bagi apologis-apologis Kristen untuk memberikan argumentasi yang lebih tajam dan akurat bagi kemajuan pemikiran teologis, khususnya mengenai Kristologi.

Tentunya bagi orang-orang percaya, khususnya kaum awam di masa kini, hal tersebut di atas menjadi sebuah kesulitan dan tantangan yang besar. Namun dengan lebih menambahkan pemahaman terhadap kebenaran Firman Allah yang hidup serta tidak abai terhadap pertumbuhan rohani secara pribadi selalu pelaku yang benar, diharapkan mampu untuk menangkis dan melawan pengajaran yang keliru dari teori tersebut.

\section{REFERENSI}

A.E. Knoch. "Kristus Dan Ketuhanan," n.d. http://www.logon.org/indonesian/s/p237.html, A.E. Knoch, Kristus dan Ketuhanan.

C. Matthew Mcmahon. "A Meditation on the Doctrine of the Person of Christ," n.d. http://www.apuritansmind.com/ChristianWalk/McMahonMeditationIncarnation.htm.

Charles C. Ryrie. Teologi Dasar. Yogyakarta: Andi offset, 2000.

Chris Marantika. Diktat Kuliah: Filsafat Dan Apologetika. Yogyakarta, 2006.

Daun, Paulus. Bidat Kristen Dari Masa Ke Masa. Manado: Yayasan Daun Family, n.d.

Dister, Nico Syukur. Teologi Sistematika. Yogyakarta: Kanisius, 2004.

Enns, Paul. The Moody Handbook of Theology. Malang: Literatur SAAT, 2004.

Evans, Tony. Teologi Allah. Malang: Gandum Mas, 1999.

Geisler, Norman L. "Baker Encyclopedia of Christian Apologetics." Grand Rapids: Baker books, 2000.

Harefa, Otieli. "Implikasi Teologis Baptisan Air Pada Keselamatan.” PASCA: Jurnal Teologi Dan Pendidikan Agama Kristen 16, no. 1 (2020): 1-14. https://doi.org/10.46494/psc.v16i1.78.

Hebert, Terry. Catatan Kuliah: Metode Pendidikan Kristen. Yogyakarta, 2006.

Herman Bavinck. "The Divine and Human Nature of Christ," n.d. www.graceonlinelibrary.org.

Lohse, Bernhard. Pengantar Sejarah Dogma Kristen. Jakarta: BPK Gunung Mulia, 1999.

Michael Bremmer. "Kenotic Theology," n.d. http://www.mbrem.com/Jesus_Christ/keno.htm, Michael Bremmer, Kenotic Theology.

Niftrik, G.C. Van dan B.J. Boland. Dogmatika Masa Kini. Jakarta: BPK Gunung Mulia, 1993.

"Pannenberg and the Chalcedonian Creed.," n.d. http://freespace.virgin.net/linz.cullen/pannenberg.html.

Peter Kreeft, Peter dan Ronald K. Tacelli. Handbook of Christian Apologetics. Downer's Grove: InterVarsity Press, 1994.

Petrus Maryono. Diktat Kuliah: Sejarah Doktrin. Yogyakarta, 2007.

Rapar, Jan Hendrik. Pengantar Filsafat. Yogyakarta: Kanisius, 2005.

Sproul, RC. Kebenaran-Kebenaran Dasar Iman Kristen. Malang: SAAT, 1997. 
"Syrac Christianity," n.d. http://syracchristianity.com/sac/Chapter II.htm.

Thiessen, C. Henry. Teologi Sistematika. Malang: Gandum Mas, 1997.

Walvoord, John F. Yesus Kristus Tuhan Kita. Surabaya: Yakin, 1969.

Zaluchu, Sonny. "Penderitaan Kristus Sebagai Wujud Solidaritas Allah Kepada Manusia." DUNAMIS: Jurnal Penelitian Teologi Dan Pendidikan Kristiani, 2017.

https://doi.org/10.30648/dun.v2i1.129. 